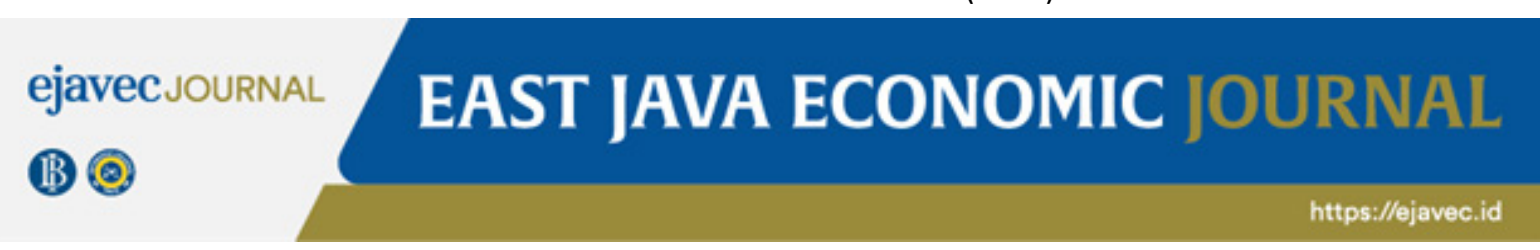

\title{
PERKEMBANGAN EKONOMI, INFLASI, DAN STABILITAS SISTEM KEUANGAN PROVINSI JAWA TIMUR \\ SEMESTER II - 2017
}

\section{Tim Penulis Laporan, Kantor Perwakilan Bank Indonesia Provinsi Jawa Timur}

Perekonomian Jawa Timur pada semester II 2017 menguat dibandingan semester sebelumnya, diiringi dengan tekanan inflasi Indeks Harga Konsumen (IHK) yang lebih rendah dan stabilitas sistem keuangan daerah masih terjaga. Akselerasi ekonomi Jawa Timur pada semester II 2017 terutama disebabkan oleh perbaikan kinerja eksternal dan peningkatan investasi. Dari sisi inflasi, berakhirnya penyesuaian tarif listrik dengan daya 900VA menopang rendahnya tekanan inflasi IHK (yoy) Jawa Timur dibandingkan paruh pertama 2017. Lebih lanjut, terjaganya stabilitas sistem keuangan Jawa Timur tercermin dari terkendalinya NPL perbankan dan terjaganya rasio keuangan korporasi.

Akselerasi kinerja perekonomian Jawa Timur yang lebih tinggi tertahan oleh perlambatan kinerja konsumsi swasta dan peningkatan impor luar negeri. Pada Semester I 2018, kinerja ekonomi Jawa Timur diperkirakan tetap tumbuh tinggi sebagaimana pertumbuhannya pada paruh kedua 2017. Optimisme tersebut ditopang oleh potensi peningkatan konsumsi swasta dan pemerintah sejalan dengan berlangsungnya Ramadhan, Idul Fitri, dan Pemilihan Kepala Daerah (Pilkada). Inflasi IHK Jawa Timur diperkirakan kembali pada sasaran inflasi $3,5 \% \pm 1 \%$ seiring meredanya tekanan inflasi di kelompok administered prices, terjaganya inflasi inti, dan rendahnya potensi peningkatan tekanan inflasi kelompok volatile food. Lebih lanjut, sejalan dengan nasional, stabilitas sistem keuangan dan kinerja perbankan Jawa Timur diperkirakan masih stabil pada paruh pertama 2018.

\section{Pertumbuhan Ekonomi Makroregional}

Kinerja ekonomi Jawa Timur pada Semester II 2017 tumbuh 5,68\% (yoy) menguat dibandingkan paruh pertama 2017 yang tumbuh 5,21\% (yoy). Dari sisi permintaan, peningkatan bersumber dari perbaikan kinerja eksternal dan penguatan investasi. Sementara itu, peningkatan kinerja lapangan usaha industri pengolahan, perdagangan, dan pertanian menjadi sumber perbaikan ekonomi Jawa Timur dari sisi sektoral. Akselerasi ekonomi Jawa Timur yang lebih tinggi tertahan oleh perlambatan kinerja konsumsi swasta dan peningkatan impor luar negeri di sisi permintaan, serta perlambatan kinerja lapangan usaha pertambangan dan jasa di sisi sektoral. ${ }^{1}$

Secara keseluruhan, kinerja ekonomi Jawa Timur tahun 2017 sedikit melambat dibandingkan tahun 2016. Pada tahun 2017 perekonomian Jawa Timur tumbuh 5,45\% (yoy), lebih rendah dibandingkan tahun 2016 yang tumbuh 5,57\% (yoy). Perlambatan tersebut disebabkan oleh penurunan ekspor luar negeri menjadi -4,26\% (yoy) di tahun 2017, terutama

\footnotetext{
${ }^{1}$ Dari sisi permintaan, konsumsi swasta dan investasi menjadi kontributor utama ekonomi Jawa Timur. Kontribusi konsumsi swasta dan investasi terhadap Produk Domestik Regional Bruto (PDRB) Atas Dasar Harga Berlaku (ADHB) Jawa Timur pada semester II 2017 masing-masing sebesar 59,86\% dan 28,46\%. Sementara kontribusi ekspor luar negeri sebesar 14,26\%. Dari sisi sektoral, industri pengolahan, perdagangan, dan pertanian merupakan tiga kontributor utama ekonomi Jawa Timur masing-masing sebesar 29,03\%, 18,18\% dan 12,80\%. 
disebabkan oleh penurunan permintaan perhiasan oleh mitra dagang utama. Sementara dari sisi penawaran, perlambatan disebabkan oleh lapangan usaha Pertanian, Kehutanan, dan Perikanan. Alih fungsi lahan pertanian ditengarai menjadi faktor utama perlambatan kinerja lapangan usaha ini.

\section{Sisi Permintaan}

Akselerasi ekspor luar negeri dan investasi menjadi sumber utama perbaikan ekonomi Jawa Timur pada paruh kedua 2017. Pada semester II 2017, kinerja ekspor luar negeri Jawa Timur tumbuh 8,33\% (yoy), meningkat dibandingkan paruh pertama 2017 yang turun $24,73 \%$ (yoy). Kinerja ekonomi mitra dagang utama Jawa Timur yakni Jepang, Amerika Serikat dan Tiongkok, yang membaik mendorong peningkatan permintaan eksternal untuk komoditas ekspor Jawa Timur (Grafik 1). ${ }^{2}$ Lebih lanjut, pemenuhan permintaan kereta api PT INKA oleh mitra dagang luar negeri serta implementasi Peraturan Menteri Perdagangan No. 38/M-DAG/PER/6/2017 tentang Ketentuan Ekspor Produk Industri Kehutanan menjadi salah satu faktor pendorong peningkatan kinerja ekspor Jawa Timur pada periode ini. ${ }^{3}$

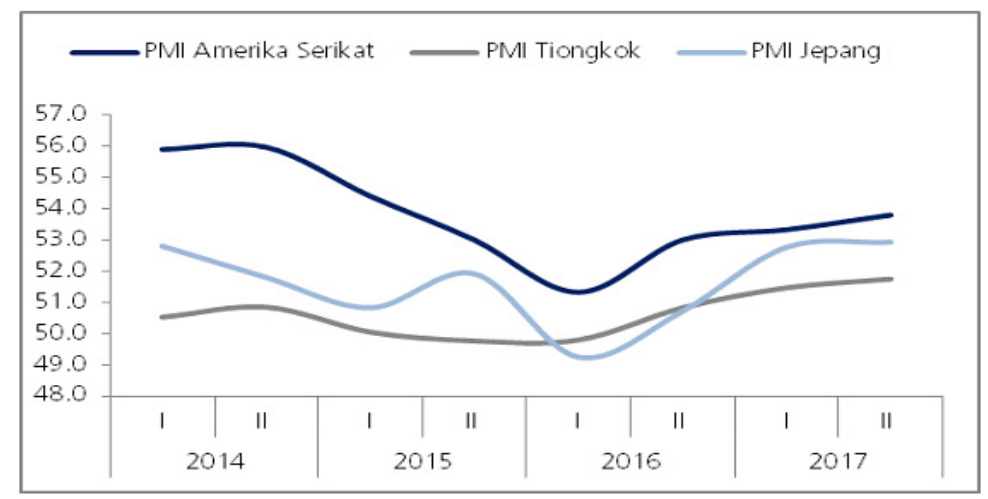

\section{Grafik 1: Indikator Kinerja Mitra Dagang Luar Negeri Utama Jawa Timur}

Kinerja investasi Jawa Timur yang membaik turut menopang pertumbuhan ekonomi Jawa Timur pada Semester II 2017. Pembentukan Modal Tetap Bruto (PMTB) yang merupakan proksi dari investasi tumbuh 6,55\% (yoy) pada semester II 2017, meningkat dibandingkan paruh pertama 2017. Peningkatan tersebut ditopang oleh masih berlanjutnya berbagai proyek pembangunan infrastruktur dan upaya peningkatan kapasitas utilisasi industri kereta api di Jawa Timur.

Tabel 1: Pertumbuhan Ekonomi Sisi Permintaan (\%,yoy)

\begin{tabular}{|c|c|c|c|c|c|c|c|c|c|c|}
\hline & \multirow{3}{*}{2014} & & & \multirow{3}{*}{2015} & & & & \multicolumn{3}{|c|}{ \%yoy, Tahun Dasar 2010} \\
\hline & & \multicolumn{2}{|c|}{2015} & & \multicolumn{2}{|c|}{2016} & \multirow{2}{*}{2016} & \multicolumn{2}{|c|}{2017} & \multirow{2}{*}{2017} \\
\hline & & $\mathbf{I}$ & II & & $\mathbf{I}$ & II & & $\mathbf{I}$ & II & \\
\hline Konsumsi Swasta & 5.74 & 4.18 & 2.76 & 3.46 & 4.13 & 4.93 & 4.54 & 5.05 & 3.98 & 4.50 \\
\hline Konsumsi Rumah Tangga & 5.60 & 4.41 & 2.69 & 3.50 & 4.06 & 4.96 & 4.50 & 5.07 & 4.02 & 4.54 \\
\hline Konsumsi LNPRT & 13.30 & -8.49 & 6.76 & -1.10 & 8.44 & 3.49 & 5.90 & 3.42 & 1.31 & 2.35 \\
\hline Konsumsi Pemerintah & 2.70 & -1.91 & 4.99 & 2.30 & 5.97 & -14.84 & -7.00 & 3.19 & 3.69 & 3.50 \\
\hline $\begin{array}{l}\text { Pembentukan Modal Tetap } \\
\text { Buto }\end{array}$ & 4.40 & 5.69 & 5.98 & 5.80 & 6.08 & 5.99 & 6.00 & 5.56 & 6.55 & 6.07 \\
\hline Bangunan & 4.60 & 5.76 & 6.37 & 6.10 & 6.47 & 6.62 & 6.50 & 5.54 & 6.87 & 6.20 \\
\hline
\end{tabular}

${ }^{2}$ Kinerja mitra dagang luar negeri direpresentasikan dengan Purchasing Manager's Index (PMI).

${ }^{3}$ Peraturan Menteri Perdagangan No. 38/M-DAG/PER/6/2017 tentang Ketentuan Ekspor Produk Industri Kehutanan yg diundangkan pada 12 Juni 2017, salah satu isinya memuat ketentuan penghapusan biaya verifikasi produk furnitur berbahan baku rotan untuk ekspor, ditengarai menjadi salah satu pendorong peningkatan ekspor kayu dan produk dari kayu Jawa Timur pada periode ini. 


\begin{tabular}{|c|c|c|c|c|c|c|c|c|c|c|}
\hline & \multirow{3}{*}{2014} & & & \multirow{3}{*}{2015} & & & & \multicolumn{3}{|c|}{ \%yoy, Tahun Dasar 2010} \\
\hline & & \multicolumn{2}{|c|}{2015} & & \multicolumn{2}{|c|}{2016} & \multirow{2}{*}{2016} & \multicolumn{2}{|c|}{2017} & \multirow{2}{*}{2017} \\
\hline & & 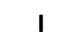 & II & & I & II & & 1 & II & \\
\hline Non Bangunan & 3.50 & 5.43 & 4.61 & 5.00 & 4.72 & 3.81 & 4.20 & 5.62 & 5.38 & 5.50 \\
\hline Ekspor Luar Negeri & -2.10 & -2.19 & -2.56 & -2.40 & 16.90 & 8.30 & 12.80 & -14.73 & 8.33 & -4.26 \\
\hline Impor Luar Negeri & 14.00 & -4.21 & -16.65 & -10.60 & -6.19 & 6.76 & 0.00 & 10.77 & 13.54 & 12.19 \\
\hline Net Ekspor Antar Daerah & 17.50 & 20.22 & -14.31 & 0.50 & -60.48 & 31.18 & 8.80 & 295.01 & 29.25 & 49.50 \\
\hline PDRB & 5.86 & 5.31 & 5.57 & 5.44 & 5.69 & 5.46 & 5.57 & 5.21 & 5.68 & 5.45 \\
\hline
\end{tabular}

Sumber: BPS (diolah)

Perlambatan kinerja konsumsi swasta dan peningkatan impor luar negeri menahan akselerasi ekonomi Jawa Timur yang lebih tinggi. Konsumsi swasta tumbuh 3,98\% (yoy) pada paruh kedua 2017, melambat dibandingkan semester I 2017 yang tumbuh 5,05\% (yoy). Perlambatan konsumsi swasta pada periode ini terutama didorong oleh kembali normalnya permintaan masyarakat pasca berlalunya momen Ramadhan dan Idul Fitri yang telah berlangsung pada paruh pertama 2017.

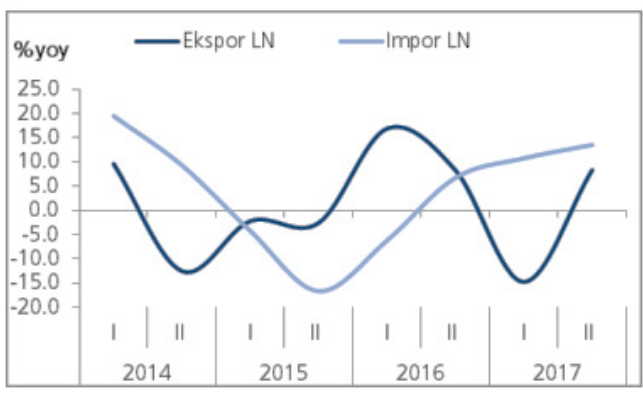

Grafik 2: Perkembangan Ekspor dan Impor Luar Negeri Jawa Timur

Sumber: BPS (diolah)

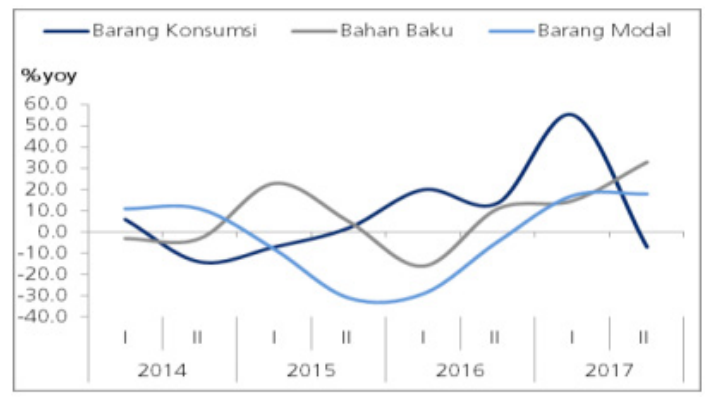

Gambar 3: Perkembangan Komponen Impor Luar Negeri Jawa Timur

Sumber: BPS (diolah)

Impor luar negeri Jawa Timur meningkat terutama untuk memenuhi peningkatan investasi. Impor luar negeri Jawa Timur tumbuh 13,54\% (yoy) pada paruh kedua 2017, meningkat dibandingkan semester sebelumnya yang sebesar $10,77 \%$ (yoy) (Grafik 2). Peningkatan impor luar negeri terjadi pada kelompok bahan baku dan barang modal sejalan dengan peningkatan investasi khususnya pada lapangan usaha industri pengolahan (Grafik 3). Sementara itu, impor barang konsumsi terpantau melambat pada periode laporan sejalan dengan perlambatan kinerja konsumsi swasta. ${ }^{4}$

\section{Sisi Sektoral}

Dari sisi sektoral, peningkatan kinerja ekonomi Jawa Timur pada paruh kedua 2017 ditopang oleh industri pengolahan, perdagangan, dan pertanian. Lapangan usaha industri pengolahan tumbuh 6,64\% (yoy) pada semester II 2017, meningkat dibandingkan periode sebelumnya (4,72\%-yoy). Peningkatan kinerja industri pengolahan terutama didorong oleh peningkatan kapasitas produksi industri transportasi Jawa Timur untuk memenuhi permintaan mitra dagang luar negeri. Kinerja lapangan usaha perdagangan juga sedikit membaik, dari tumbuh 6,13\% (yoy) menjadi tumbuh 6,37\% (yoy) pada semester II 2017. Lebih lanjut, kinerja lapangan usaha pertanian tumbuh 1,72\% (yoy) pada paruh kedua 2017, membaik dibandingkan paruh pertama 2017 (1,25\%-yoy), disebabkan oleh panen raya hortikultura yang terjadi ${ }^{4}$ Kinerja impor pada Semester II 2017 dibandingkan Semester I 2017, yaitu : impor bahan baku (dari tumbuh 14,76\%-yoy menjadi 33,00\%yoy), impor barang modal (dari tumbuh 17,14\%-yoy menjadi 18,00\%-yoy), impor barang konsumsi (dari tumbuh 55,28\%-yoy menjadi -7,00\%yoy). Sementara kinerja industri pengolahan Jawa Timur meningkat dari tumbuh 4,72\% (yoy) menjadi 6,64\% (yoy). 
di Jawa Timur.

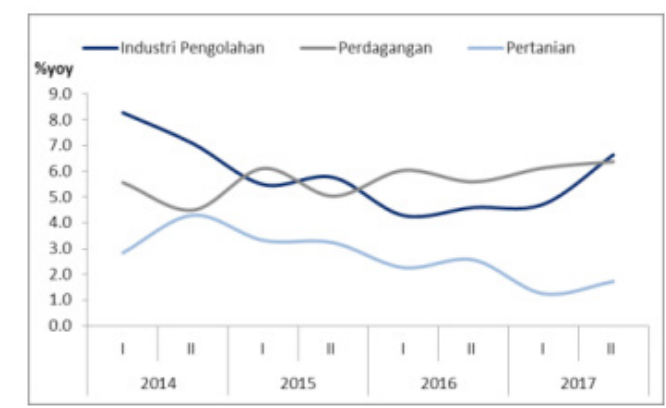

Grafik 4: Pertumbuhan Sektor Pertanian, Industri Pengolahan, dan Perdagangan Jawa Timur

Sumber: BPS (diolah)

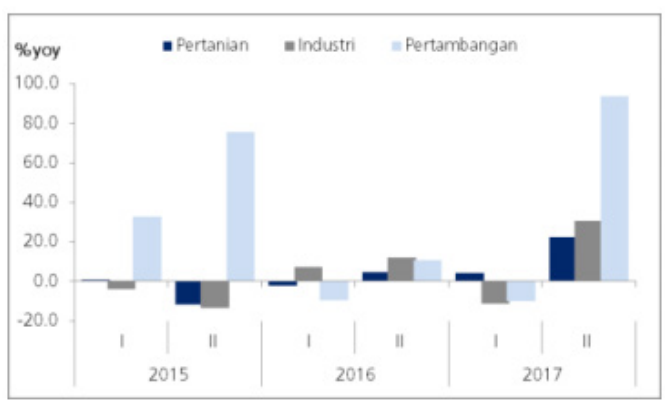

Gambar 5: Pertumbuhan Ekspor Pertanian, Industri Pengolahan, dan Pertambangan Jawa Timur

Sumber: BPS (diolah)

Akselerasi ekonomi Jawa Timur yang lebih tinggi tertahan oleh perlambatan kinerja lapangan usaha penyediaan akomodasi dan makan minum, serta lapangan usaha jasa pendidikan. Lapangan usaha akomodasi dan mamin tumbuh $7,04 \%$ (yoy) pada paruh kedua 2017 , melambat dibandingkan periode sebelumnya ( $8,85 \%$ yoy). Perlambatan tersebut sejalan dengan kembali normalnya permintaan masyarakat pasca Ramadhan dan Idul Fitri yang telah terjadi pada Semester I 2017. Sementara itu, perlambatan kinerja lapangan usaha jasa pendidikan (dari 4,23\%-yoy menjadi 3,76\%-yoy) disebabkan oleh telah berlalunya tahu ajaran baru untuk kelompok Sekolah Dasar (SD), Sekolah Menengah Pertama (SMP), dan Sekolah Menengah Atas (SMA) yang telah terjadi pada Semester I 2017.

Inflasi

Pada semester II 2017, Indeks Harga Konsumen (IHK) Jawa Timur mencatat inflasi 4,04\% (yoy) lebih rendah dibandingkan semester I 2017 yang sebesar 4,66\% (yoy) (Grafik 6). Lebih rendahnya inflasi IHK semester II 2017 terutama bersumber dari perlambatan tekanan inflasi pada kelompok inti dan administered prices. Sementara itu, kenaikan tekanan inflasi pada kelompok volatile food menahan perlambatan inflasi IHK yang lebih dalam.

Inflasi inti melambat terutama disebabkan oleh perlambatan kelompok non traded. Inflasi inti pada paruh kedua 2017 sebesar 3,26\% (yoy), melambat dibandingkan semester I 2017 (3,87\%-yoy). Berdasarkan komponennya, perlambatan tersebut disebabkan oleh kelompok core non-tradable (dari 5,52\%-yoy menjadi 4,06\%-yoy), sementara inflasi kelompok core tradable justru meningkat (Grafik 7). Penurunan inflasi kelompok core non tradable pada semester II 2017 dipicu oleh perlambatan permintaan kelompok jasa, khususnya jasa pendidikan sejalan dengan telah berlalunya momen Tahun Ajaran Baru yang telah berlangsung pada Semester I 2017. Sementara itu, peningkatan inflasi kelompok core tradable (dari 2,16\%-yoy menjadi 2,41\%-yoy di semester II 2017) didorong oleh depresiasi nilai tukar Rupiah terhadap Dollar Amerika Serikat. Pada Desember 2017, nilai tukar Rupiah terhadap Dollar Amerika Serikat mengalami depresiasi 1,08\% (point to point). Penguatan nilai tukar Dollar Amerika Serikat terhadap mata uang lain ditopang oleh kenaikan Fed Fund Rate secara gradual dan normalisasi neraca The Fed yang menyebabkan kenaikan investasi ke Amerika Serikat.

Tekanan inflasi kelompok administered prices (AP) pada semester II 2017 lebih rendah dibandingkan paruh pertama 2017. Pada semester II 2017, kelompok administered 
prices mencatat inflasi 10,69\% (yoy), melambat dibandingkan semester I 2017 yang sebesar $12,35 \%$ (yoy). Perlambatan tekanan inflasi kelompok ini terutama ditopang oleh berakhirnya penyesuaian tarif listrik dengan daya 900VA yang telah berlangsung pada semester I 2017.

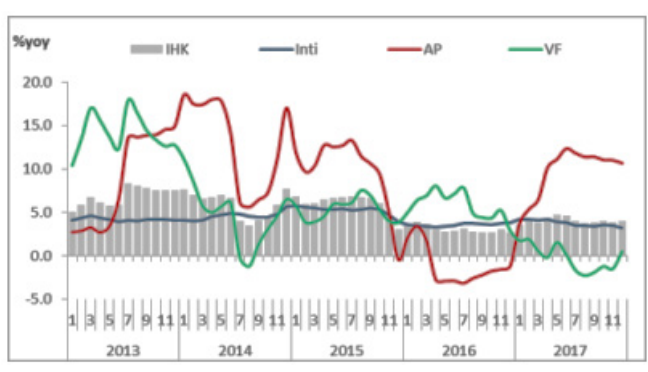

Grafik 6: Perkembangan Inflasi Jawa Timur, 2012-2017

Sumber: BPS (diolah)

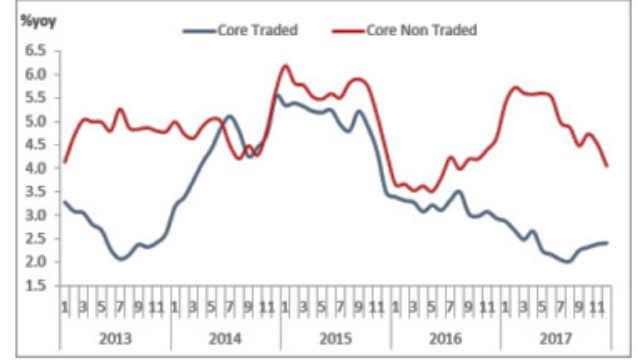

Gambar 7: Perkembangan Inflasi Inti Inflasi Jawa Timur, 2012- 2017

Sumber: BPS (diolah)

Perlambatan inflasi IHK yang lebih dalam tertahan oleh peningkatan tekanan inflasi kelompok volatile foods. Kelompok volatile foods (VF) pada semester II 2017 mencatat inflasi sebesar 1,62\% (yoy), meningkat dibandingkan semester I 2017 yang sebesar 0,16\% (yoy). Peningkatan tersebut didorong oleh masih berlangsungnya masa tanam komoditas padi serta penetapan Harga Eceran Tertinggi untuk beras jenis medium dan premium.

\section{Perkembangan Stabilitas Sistem Keuangan Daerah}

Kondisi sistem keuangan daerah tetap terjaga di tengah perlambatan kinerja Rumah Tangga (RT) dan terbatasnya kinerja sektor korporasi. Terjaganya stabilitas keuangan daerah Jawa Timur tercermin dari Non Performing Loan (NPL) yang terjaga di kisaran 3\% serta rasio keuangan korporasi, khususnya produktivitas, likuiditas, dan repayment capacity masih terjaga dengan baik.

Pada semester II 2017, pertumbuhan penyaluran kredit perbankan melambat. Kredit perbankan tumbuh 8,23\% (yoy), melambat dibandingkan semester I 2017 (8,37\% yoy). Perlambatan kredit perbankan utamanya terjadi pada kredit konsumsi dan kredit investasi. ${ }^{5}$ Perlambatan kredit konsumsi sejalan dengan melambatnya konsumsi swasta seiring berlalunya momen Ramadhan, Idul Fitri, dan Tahun Ajaran Baru yang telah berlangsung pada paruh pertama 2017. Sementara pelambatan pertumbuhan kredit investasi ditengah membaiknya kinerja investasi Jawa Timur, ditengarai karena sebagian besar penyaluran kredit investasi telah dilakukan pada semester I 2017. Lebih lanjut, peningkatan Penanaman Modal Asing Jawa Timur pada semester II 2017 ditengarai turut menjadi sumber pembiayaan investasi Jawa Timur pada periode laporan. ${ }^{6}$

\footnotetext{
${ }^{5}$ Kredit investasi Jawa Timur pada semester II 2017 tumbuh 6,43\% (yoy), melambat dibandingkan semester I 2017 yang tumbuh 15,16\% (yoy). Demikian pula dengan kredit konsumsi, yang melambat dari tumbuh 12,96\% (yoy) menjadi 12,38\% (yoy).

${ }^{6}$ Berdasarkan Dinas Penanaman Modal Provinsi Jawa Timur, Penanaman Modal Asing (PMA) Provinsi Jawa Timur pada semester II 2017 sebesar Rp12,57 triliun, meningkat dibandingkan Semester I 2017 yang sebesar Rp8,92 triliun.
} 


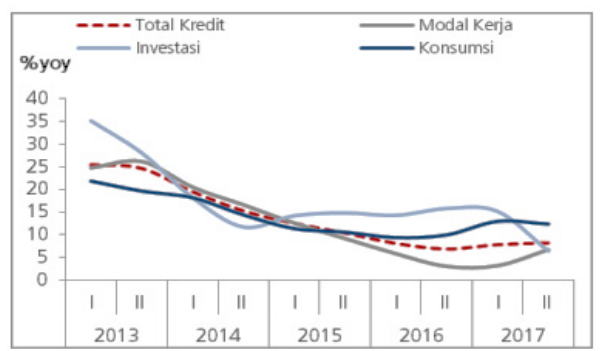

Grafik 8: Perkembangan Pertumbuhan Kredit Menurut Penggunaan Lokasi Proyek Jawa Timur

Sumber: BPS (diolah)

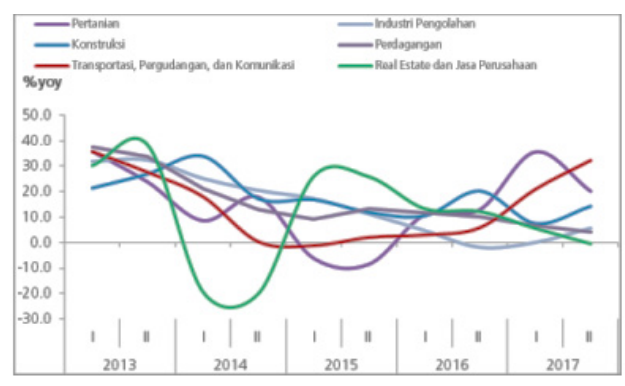

Gambar 9: Perkembangan Pertumbuhan Kredit Sektoral Lokasi Proyek Jawa Timur

Sumber: BPS (diolah)

Pertumbuhan Dana Pihak Ketiga (DPK) pada semester II 2017 melambat. DPK tumbuh 9,61\% (yoy), melambat dibandingkan semester sebelumnya yang sebesar 9,88\% (yoy) (Grafik 10). Berdasarkan komponennya, perlambatan kinerja DPK disebabkan oleh deposito, sementara pertumbuhan giro dan tabungan meningkat.

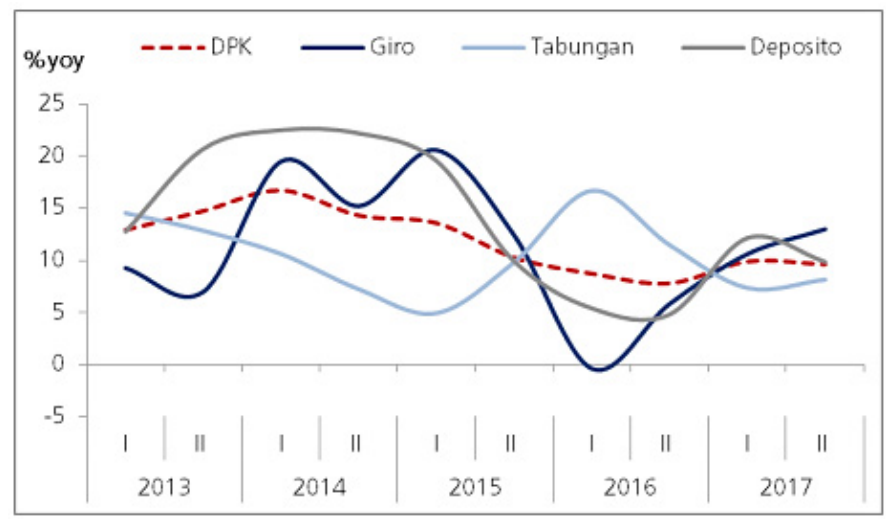

Grafik 10: Perkembangan Pertumbuhan DPK

Risiko kredit perbankan stabil. Rasio NPL perbankan pada semester II 2017 sebesar $3,15 \%$ relatif stabil dibandingkan semester sebelumnya yang mencapai 3,14\%. Meskipun demikian, secara sektoral terdapat peningkatan NPL dibandingkan semester I 2018 khususnya pada kredit sektor konstruksi (dari 3,19\% menjadi 3,28\%) dan kredit sektor perdagangan (dari $4,93 \%$ menjadi 5,00\%). Kenaikan NPL yang lebih tinggi tertahan oleh penurunan NPL kredit sektor transportasi (dari 2,92\% menjadi 2,30\%). Stabilnya rasio NPL di tengah terbatasnya kinerja korporasi dan perlambatan sektor rumah tangga menunjukkan repayment capacity yang baik dan mengindikasikan masih kuatnya ketahanan kedua sektor tersebut.

\section{Prospek Perekonomian}

Bank Indonesia memperkirakan perekonomian Jawa Timur pada semester I 2018 tetap tumbuh tinggi sebagaimana pertumbuhannya pada paruh kedua 2017. Pertumbuhan diperkirakan bersumber dari peningkatan kinerja konsumsi swasta sejalan dengan berlangsungnya Ramadhan, Idul Fitri, serta Tahun Ajaran Baru. Lebih lanjut, konsumsi pemerintah juga diperkirakan meningkat ditopang oleh berlangsungnya Pemilihan Kepala Daerah (Pilkada) di 17 kabupaten/ kota di Jawa Timur pada akhir semester I 2018. Dari sisi eskternal, surplus 
perdagangan Jawa Timur diperkirakan meningkat sejalan dengan ekspor yang semakin kuat dan perlambatan kinerja impor luar negeri. Sementara itu, meskipun masih tumbuh postif, pertumbuhan kinerja investasi pada semester I 2018 diperkirakan melambat dibandingkan semester II 2017 sebagaimana polanya di paruh pertama dan akan lebih optimal pada paruh kedua tahun berjalan.

Pada paruh pertama 2018, inflasi Indeks Harga Konsumen (IHK) Jawa Timur diperkirakan tetap terkendali dan berada kisaran sasaran inflasi 2018 , yaitu $3,5 \pm 1 \%$. Inflasi IHK Jawa Timur pada semester I 2018 diperkirakan melambat dibandingkan pencapaian paruh kedua 2017 yang sebesar 4,04\% (IHK) dan berada di kisaran 3,5 $\pm 1 \%$. Lebih rendahnya tekanan inflasi bersumber dari kelompok administered prices sejalan dengan kebijakan Pemerintah pusat yang tidak menaikan tarif listrik kelompok rumah tangga pada paruh pertama 2018. Sementara itu, tekanan inflasi pada kelompok volatile food pada periode laporan diperkirakan meningkat dibandingkan paruh kedua 2017. Peningkatan tekanan inflasi pada kelompok ini disebabkan oleh masih berlangsungnya masa tanam komoditas padi pada awal tahun 2018 serta kenaikan permintaan musiman komoditas pangan pada periode Ramadhan dan Idul Fitri yang jatuh pada paruh pertama 2018. Lebih lanjut, inflasi inti diperkirakan stabil dibandingkan semester lalu sejalan dengan kinerja ekonomi domestik yang mampu merespon permintaan internal dan nilai tukar Rupiah yang terjaga.

Bank Indonesia akan terus mencermati beberapa risiko dalam perekonomian ke depan. Dari sisi global, kinerja ekonomi Tiongkok yang diperkirakan mengalami rebalancing di tahun 2018 berpotensi menghambat kinerja ekspor Jawa Timur dimana Tiongkok merupakan salah satu negara mitra dagang utama Jawa Timur. Kebijakan perdagangan proteksionisme yang diimplementasikan oleh Amerika Serikat berpotensi menekan kinerja ekspor Jawa Timur. Lebih lanjut, normalisasi neraca Bank Sentral Amerika Serikat secara bertahap berpotensi menarik investasi asing ke negara tersebut dan mempengaruhi nilai tukar. Dari sisi domestik, peningkatan cukai rokok di tahun 2018 diperkirakan terus memberikan tekanan bagi perusahaan rokok di Jawa Timur yang dapat mempengaruhi performa sektor perdagangan. 